\title{
RESEARCH ARTICLE \\ Bridging MindBodySpirit in a Borderlands ReFraming of Disability
}

\author{
Maricela DeMirjyn, PhD
}

Department of Ethnic Studies, Colorado State University - United States (Colorado).

\begin{abstract}
The following articles engages with the written works by Gloria Anzaldúa as a disability theorist implementing a mindbodyspirit aesthetic. Additionally, Anzaldúa's constructions of spiritual mestizaje and Nepantla are discussed as platforms for the integration of multible subiectivities.
\end{abstract}

\section{Keywords}

Anzaldúa; disability; Nepantla; spiritual mestizaje

\section{Introduction}

Open Access

Citation: DeMirjyn M. Bridging MindBodySpirit in a Borderlands ReFraming of Disability. Gender and Women's Studies. 2020; 3(1):3.

Received: August 25, 2019

Accepted: August 08, 2020

Published: August 22, 2020

Copyright: @ 2020 DeMirjyn M. This is an open access article distributed under the terms of the Creative Commons Attribution License, which permits unrestricted use, distribution, and reproduction in any medium, provided the original author and source are credited.

\section{Corresponding author:}

Maricela DeMirjyn, Department of Ethnic Studies, Colorado State

University - United States (Colorado). E-mail:

demirjyn@colostate.edu
My companion, a wooden serpent staff with feathers, is to my right while I ponder the ways metaphor and symbol concretize the spirit and etherealize the body - Anzaldúa

An influential thinker and foremother of Chicana feminism, Gloria Evangelina Anzaldúa used autohistoria-teoría as the act of self-writing to create knowledge (2009). Her autoethographic works express the processes by which she came to reframe and understand her various identities as a queer, brown working-class woman with disabilities. Anzaldúa's (2002) familiarity with disability is shared from her childhood memories of shame to the reconceptualization of her body influenced by a lifelong engagement with conocimiento, an increased embodied self-awareness. Scholars label the reframing of her multiple minoritized identities as the development of a "crip-queer-mestiza-subjectivity" (Ramlow 2006, 175). However, the argument of this essay is to shift the framing of multiple identities and selfhood to be inclusive of spirituality in an act of bridging bodymindspirit, thereby promoting an understanding of all aspects contributing to the Self as sacred and to be honored. In her own words, Anzaldúa describes the above praxis as achieving "bodymindsoul" (2002, 554), although in a later interview with Dr. Irene Lara (2008), specialist in Anzaldúan theory and Chicana spirituality, she references mindbodyspirit. By using mindbodyspirit as a conceptual modality for discussions centering embodied subjectivity, theory in the flesh "where the physical realities of our lives" (Moraga and Anzaldúa 1983, 23) engages with "spiritual mestizaje" (Anzaldúa 1987). Together this represents a process for "the transformative renewal of one's relationship to the sacred through a radical and sustained multimodal and self-reflexive critique of oppression in all its manifestations" (Delgadillo 2011, 1). This work engages with Anzaldúa's notions of disability and chronic illness, and the ways in which a mindbodyspirit praxis allows for a reframing of selfhood.

Anzaldúa had two physical conditions, as well as bouts of depression, that affected her life experiences and contributed to the development of her theories to be discussed shortly, including Nepantla, the Coatlicue state and the Coyolxauhqui imperative $(1987,2015)$. One condition developed at the onset of her birth, "a rare hormone disorder that caused her to begin menstruating in infancy and led to an emergency hysterectomy in adulthood" 
(McMaster 2008, 102). Anzaldúa remembered her body as always being in pain. "It was horrendous, because out of every twenty-four days - my period came every twenty-four days - ten of them were painful. I had fevers of 106, tonsillitis every time, throwing up. Horrendous pain all the time, all the time, all the time" (Weiland 2000, 87). As she aged and became a young girl, Anzaldúa described sensing feelings of shame for being different and selfperceptions of being bad or dirty. In a passage taken from Borderlands/La Frontera: The New Mestiza (1987), she references her experiences as being a "mutant stoned out of a herd, something deformed with evil inside" and learning early in life "that something was fundamentally wrong" with her (Anzaldúa 1999, 64-65). This coincides with a remark from Anzaldúa in an interview regarding her realization of being "really strange, really different from everyone else" at age five or six when her breasts started growing (Weiland 2000, 79). These feelings of shame and guilt became triggers for what she referenced as her shadow beast, "the rebel" inside her that refused authority and constraints (Anzaldúa 1987/1999, 38). She discovered by embracing her beast and facing her fears, her conocimiento grew along with an understanding of who she was by shifting her beliefs away from oppressive paradigms and incorporating her own ways of knowing. Diabetes, her second condition, developed during her adulthood and is believed to have been a contributing cause to her early death at age 61. Anzaldúa recalled that when she became diabetic, she had to stop everything because she could barely function (Keating 1998-1999). Once diagnosed with type 1 diabetes, she went through a journey of emotions spanning from anger to sadness. Anzaldúa labeled these emotions as "negative feelings" and refers to experiencing depression (2002, 552). Suzanne Bost, Anzaldúan scholar, adds that diabetes altered Anzaldúa's attentiveness and "perhaps most significantly, her way of relating to her own body" (2010, 195). Using her childhood condition as an analogy, the emotions linked to Anzaldúa's initial experiences of diabetes again triggered her shadow beast and awakened her conocimiento to a new embodied awareness or as she states, "body consciousness" (2002, 553). Resultantly, Anzaldúa began seeing her diabetic symptoms "not as signs of sickness and disintegration, but as signals of growth" (2002, 552). She also referenced depression as being useful in signaling the need to make life changes, thereby evoking the shadow beast and prompting self-awareness, as well as agency $(2002,553)$.

In this stage of Anzaldúa's autohistoria-teoría, she begins to apply a more fully integrated mindbodyspirit sensibility of self and describes this practice as "putting all the pieces together in a new form" $(2002,546)$. As a way of reconceptualizing diabetes, it became her "spiritual teacher" (Reti 2008, 59). Anzaldúa stated "ritual, mediation, affirmation and strengthening" became ways of engaging with diabetes and reframing the self-alienating and disempowering societal narratives surrounding disability and chronic illness (Weiland 2000, 98). Renown feminist disability scholar, Rosemarie Garland-Thomson refers to these "narratives of the body" as cultural fabrications used to assert power and control in the form of ableism (2011, 17). Through the praxis of mindbodyspirit, Anzaldúa not only reframed her experiences and conocimiento regarding both of her physical conditions, but she also reengaged with her understanding of identity and identity politics in general. She realized after thirty years of repressing her body, identity is made up of spirit, emotion and body, and it has roots with all people and beings $(2002,560)$. The origins of her theoretical work with mindbodyspirit, as well as the reframing of self in connection with identity, is traced back to Anzaldúa's interest in Azteca-Mexica goddesses, particularly with Coatlicue and Coyolxauhqui.

Coyolxauhqui, known as the Moon Goddess, is said to have been dismembered by her brother, Huitzilopochtli, a war and sun god. Anzaldúa likened the dismembering of Coyolxauhqui to her own sense of being emotionally, mentally and physically torn apart by society as a racialized and sexualized Other. She first viewed Coyolxauhqui at the Denver Museum of Natural History called "Aztec: The World of Moctezuma" during a search for traces of her "mestiza lineage" and Native ancestry (1998, 163). According to Debra Blake, scholar of Chicana archetypes, Anzaldúa associated Coyolxauhqui not only with herself, but with the disfigured and broken people she sought to empower with her writings and praxis of mindbodyspirit (2008, 70-71). In later writings, it's clear that in part what continually drew Anzaldúa to Coyolxauhqui was the conceptualization of a process by which fragmented pieces of oneself are brought together again in ways expressing "new notions of yourself and reality" $(2002,562)$. She viewed this process as healing, complex and involving the creation of new stories, or as she referenced, "new personal myths." (2002, 559-560). With time, Anzaldua theorized the above as representing the Coyolxauhqui imperative, a "process of disintegration and reconstruction" $(2015,86)$. 
She recognizes the difficulty in the praxis of this theory in the following statement:

Cultural ideas (such as what's honorable or cowardly, manly or womanly) and their taken-for-granted truisms are imbibed at a young age and become life's givens, a familiarity that makes us feel secure. It can be hard to adopt new ideas and new ways of seeing, especially if these new perspectives seem threatening and make us doubt or distrust our core sense of self. Change generally produces tension because it has no sense of closure, completion, or boundaries. $(2015,86)$.

This revisioning or restructuring of one's narratives ties in with Chicana scholar, Emma Perez's (1999) notion of the decolonial imaginary by creating new narratives and ways of understanding in an expansive manner regarding culture, history and identity. In doing so,

systemic institutions run by structures of power and privilege supporting heterosexist, racist, classist and ableist ideologies are no longer recognized as viable and the process of institutional decolonization at every level is called into action. Anzaldúa speaks of Coyolxauhqui as being the light in the dark, helping bring forward new possibilities where mind, body and spirit intricately connect in complex ways leading to new understanding of ourselves and our shared stories $(2002,562)$.

In order to begin a deeper understanding of how mindbodyspirit is developed alongside the process of dismantling internalized dominant narratives pertaining to identity, a step back into the Anzaldúan borderlands is required. Her previously mentioned seminal work, Borderlands/La Frontera (1987) provides readers many key theoretical tools, but of primary interest to this essay in connection with the praxis of mindbodyspirit are Nepantla and the Coatlicue state. Nepantla is considered a transitional in-between space that becomes accessible during periods of conocimiento, or what audience members come to recognize as "aha moments" when everything clicks into place after a glimmer of insight occurs. Anzaldúa describes being in Nepantla as experiencing reality as "fluid, expanding and contracting" and she goes on to add the below explanation:

In nepantla you are exposed, open to other perspectives, more readily able to access knowledge derived from inner feelings, imaginal states, and outer events and to 'see through' them with a mindful, holistic awareness. Seeing through human acts both individual and collective allows you to examine the ways you construct knowledge, identity and reality, and explore how some of your/others' constructions violate other people's ways of knowing and living. (2002, 544).

Anzaldúa references being in a constant state of "mental nepantlism" as a person with multiple and mixed identities $(1987 / 1999,100)$. It is during this state that she was able to tap into an integrated mind, body and spiritual connection by tuning into what her body thought, felt and sensed. (Lara 2008). Essentially, Anzaldúa was able to embody a praxis of mindbodyspirit.

Another way of thinking about Nepantla is as a middle space serving as a site for making meaning within a psychological, spiritual and/or political context (Medina 2010, 211). In the case of disability and chronic illness, Bost interprets Nepantla as a way station where conditions, deemed as pathological by society, are embraced thereby allowing for emotions and thoughts to surpass status quos (2010b). Therefore, reaching Nepantla through brief moments of conocimiento is the first step toward developing a mindbodyspirit practice, as well as beginning the process of unmasking self-representations based on past personal stories of shame and guilt or internalized feelings of being less than. Trigger the shadow beast and create new stories of identity! From a communal perspective, Nepantla also provides a space for the creation of new paradigms to house new realities and belief systems, including the ways in which differing identities are perceived and represented. Anzaldúa viewed mindbodyspirit as a greater identity category which connected all peoples, as well as fauna and flora. However, this essay argues that she wasn't necessarily advocating for a dismissal or erasure of all identities pertaining to ethnicity, gender, sexuality, disability, religion and so forth, rather Anzaldúa encouraged individuals to reframe any negative self-perceptions derived from what she believed to be false and dangerous narratives in relation to identity designed to empower only a select group of people. To this point, she regarded Nepantla as providing access to "inner reflection and vision - the mental, emotional, instinctive, imaginal, spiritual, and subtle bodily awareness - with social, political 
action and lived experiences to generate subversive knowledges" (Anzaldúa 2002, 542). Such revolutionary ways of knowing creates space for challenging the "supposed predictability of identities" and shift the "boundaries around and between bodies" (Bost 2010, 18). The next stage in advancing toward a mindbodyspirit embodiment occurs through the Coatlicue state.

Like her interest in Coyolxauhqui, Anzaldúa was drawn to the Creatrix goddess, Coatlicue. Coatlicue, known as the Serpent Goddess, was Coyolxauhqui's mother in the Aztec-Mexica pantheon. The Snake Goddess is depicted as having "a human skull or serpent for a head, a necklace of human hearts, a skirt of twisted serpents and taloned feet" (Anzaldúa 1987/1999, 49). "She is a symbol of the fusion of opposites: the eagle and the serpent, heaven and the underworld, life and death, mobility and immobility, beauty and horror" (Anzaldúa 1987/1999, 69). Coatlicue's fate was to be labeled an idol by Catholic priests during the Conquest, and her image was banished from open worship. "She was associated with the figure of the serpent, a creature much maligned in the Christian tradition, but often sacred and revitalizing in indigenous worlds" (Delgadillo 2011, 1). For Anzaldúa, Coatlicue became a metaphor for the state of internal struggle occurring when new stories arise from the ashes of old stories, and previous paradigms for understanding the world and selfhood are proven false. She named this stage of growing conocimiento, the Coatlicue state (1987/1999, 68). Anzaldúa spoke to the difficulty of being in the Coatlicue state, as she associated it with fear and the feeling of exposure, or vulnerability. But, as she acknowledged in her writings, there exists a cost for "every increment of consciousness" and if the new knowledge gained by awareness is refused, then there is no moving forward on one's path $(1987 / 1999,70)$.

The following description taken from Borderlands/La Frontera, and told in the third person, provides readers with insights as to why Anzaldúa willingly entered the Coatlicue state:

Why does she have to go and try to make "sense" of it all? Every time she makes "sense" of something, she has to "cross over," kicking a hole out of the old boundaries of the self and slipping under or over, dragging the old skin along, stumbling over it. It hampers her movement in the new territory, dragging the ghost of the past with her. It is a dry birth, a breech birth, a screaming birth, one that fights her every inch of the way. It is only when she is on the other side and the shell cracks open and the lid from her eyes lifts that she sees things in a different perspective. It is only then that her consciousness expands a tiny notch, another rattle appears on the rattlesnake tail and the added growth slightly alters the sounds she makes. Suddenly the repressed energy rises, makes decisions, connects with conscious energy and a new life begins. (1987/1999, 71).

The Coatlicue state is where change is processed regarding ideologies, beliefs systems, perceptions of realities and one's personhood. Likening the Coatlicue state to being in a transitory phase of awareness, Anzaldúa speaks to it as a place where "the psyche can assimilate previous experiences" $(1987 / 1999,68)$. Both Nepantla and the Coatlicue State are intertwined. Lara Medina, specialist in Chicana spirituality, states, "We can choose to move through the shadow side of nepantla into the light within nepantla, or beyond the 'Coatlicue state,' learning from the lessons that the forces of creation and destruction offer" $(2014,170)$. As Anzaldúa shared in an interview, "When you come out of the Coatlicue state you come out of nepantla, this birthing stage where you feel like you're reconfiguring your identity" (Blake and Abrego 2000, 225-226). A way of linking the above explanation to the development of a mindbodyspirit selfhood is that the process is fluid and continually requires the entering and exiting of Nepantla. The resistance endured in the Coatlicue state leads to changes as past experiences are "worked on" and "connected to the soul, connected to making soul" (Blake and Abrego 2000, 226). This reference to making soul comes from a phrase used by the Nahuas and borrowed by Anzaldúa (1990), "making face, making soul" which loosely translates to we craft our own face (body) and heart (soul). In the introduction to an anthology by feminists of color, she states:

We begin to acquire the agency of making our own caras. "Making faces' is my metaphor for constructing one's identity. You are the shaper of your flesh as well as of your soul. ... In our self-reflectivity and in our active participation with the issues that confront us, whether it be through writing, front-line activism, or individual selfdevelopment, we are also uncovering the inter-faces, the very spaces and places where our multiple-surfaced, colored, racially gendered bodies intersect and 
interconnect. (1990, xvi).

Anzaldúa described that while in the Coatlicue state, she would write stories and feel as though she was creating her own face and her own heart (1987/1999, 95).

She further explained that during these times she was able to incorporate voices and scenes into "film-like narratives" with the images representing "residues of trauma" (Anzaldúa 1987/1999, 92). For her, these images provided an opportunity for her to reconstruct their significance and make meaning from them in a way that was healing. Again, crafting new stories from the old stories provides space for the creation of fresh realities and the reframing, or changing, of identities. As Anzaldúa stated, "You used to be this person but now maybe you're different in some way. You're changing worlds and cultures and may be classes, sexual preferences" and so on (Blake and Abrego 2000, 225-226). Writing or creating stories in this manner becomes a tool for resistance against negative societal ideologies and beliefs resulting from colonization (Anderson 2000, 140). This process is reminiscent of what Mark Freeman, narrative scholar, refers to as "autobiographical consciousness" which is when "one finds via personal history the pathway to identity (2001, 287). In turn, as the next stage of developing an embodied sense of mindbodyspirit, the Coatlicue state provides the stimulus for the praxis of personal storytelling, where values and beliefs can be "revived and regenerated" (Ouellette 2002, 89). These new personal stories, as well as new imaginings of realities, circularly return the storyteller to the realm of the Coyolxauhqui imperative. Here the new stories become new myths, epistemologies are shaped by theories in the flesh, and new understandings of identity are formed. The groundwork for developing a larger mindbodyspirit sense of self is set and the realization of its praxis as a life-long process that comes with moments of conocimiento.

Anzaldúa shared that she wrote the myths in her, the myths she was, and the myths she wanted to become. And in doing so, she felt that "the word, the image and the feeling have a palpable energy, a kind of power" (Anzaldúa 1987/1999, 93). Additionally, she viewed her stories as living with energy, whether read quietly or out loud. To her, stories became "both a physical thing and the power that infused it" (Anzaldúa 1987/1999, 93). A way of contextualizing all the different strands that led Anzaldúa to creating theoretical modalities, such as Nepantla, the Coatlicue state and the Coyolxauhqui imperative, and visualizing the power in creating autohistoria-teoría is twofold: One, through a discussion of spirituality, particularly from an Chicana-Indigena way of honoring spirit, and two, reflecting on her approach to incorporating disability within a mindbodyspirit framework. The essay concludes with a focus on the development and praxis of mindbodyspirit within Nepantla, for beginners to Elders and all of us in between. Anzaldúa believed that "we have to keep evolving as souls, as minds, as bodies - on all different planes" (Weiland 2000, 75). The potential for change and radical imagination are interlinked, and storytellers have the power to shape new ways of knowing.

Anzaldúa began exploring the praxis of mindbodyspirit as she created her own stories pertaining to identity. As previously mentioned, she was drawn to indigenous Azteca-Mexica deities in part because she was looking for her past and her ancestry. Chicanx access to stories and memories pre-Conquest is limited and the stories that remain are reinterpretations from the perspective of the colonizers. Many of the new stories created about Chicanx indigenous roots are being reborn from ashes, as well as from oral histories passed down generationally and from codices or other writings that were not destroyed. Anzaldúa recognized spirituality as playing a key role in the development of one's self. She distinguished the difference between organized religion, such as Catholicism, and spirituality, particularly a practice of spiritual mestizaje or blending of spiritualties. In developing her own pantheon, she incorporated the goddesses Coyolxauhqui and Coatlicue because of what they represented, and because she felt connected to their stories. Additionally, she reengaged with Coatlalopeuh, who was known to her as a child raised in the Catholic faith as the Virgin of Guadalupe, the brown Madonna. Coatlalopeuh has many names, but primarily known as Tonantzin, Mother Earth. Anzaldúa chose to refer to her as Coatlalopeuh due to the significance of what the name meant. In Nahuatl, coatl means "serpent" and lopeuh refers to "the one who has dominion over serpents." Anzaldúa added her own translation to lopeuh to signify "the one who is at one with the beasts" $(1987 / 1999,51)$. The translation serves two meanings for her, as it speaks to her own relationship to snakes as guides and it references her theory regarding shadow beasts. 
This exercise of molding one's own spiritual icons and beliefs is directly connected to spiritual mestizaje. Spiritual mestizaje is defined as "the transformative renewal of one's relationship to the sacred through radical and sustained multimodal and self-reflexive critique of oppression in all its manifestations and a creative and engaged participation in the shaping of life that honors the sacred" (Delgadillo 2011, 1). In her Borderlands/La Frontera text, Anzaldúa critiques the use of the Virgin of Guadalupe to symbolize the "good" or virtuous, read virginal, woman within Chicanx and Latinx culture and the overall dichotomy of good vs. bad in relation to gender expectations and sexuality. This is one example of how she enacted spiritual mestizaje to critique the Church's rendition of the Virgin as a method to control and disempower women, while at the same time reclaiming the Virgin's origins as Coatlalopeuh. For Anzaldúa, spiritual mestizaje provided an avenue for self-understanding and selftransformation. She viewed it as a method for reconstituting a mindbodyspirit embodiment, one that was holistic and entailing a sense of spirituality alongside mental and physical states (Keating 1998-1999). To this end, Perez points out that "colonization may have destroyed our indigenous civilizations, but colonization could not eliminate the evolution of an indigenous psyche" $(2005,2)$.

It is with this sense of spirituality that Anzaldúa crossed into the borderlands with her writings. She viewed the act of writing as an artistic and shamanic-like performance, and she began her writing process as a ritual with a prayer as "an affirmation and a voicing of intent" combined with "offerings of incense and cracked corn" (Anzaldúa 1987/1999, 89). In her works, she effectuated a mindbodyspirit embodiment by using reflexive questioning to link emotions, mental states of being, sensations of the body and perceptions of the self as sacred. Unfortunately, few scholars have taken-up Anzaldúa's writings with an emphasis on spirituality, spiritual mestizaje or the praxis of mindbodyspirit, including spiritual activism. This may be attributed to the face that "references to spirit, souls, the sacred, and other such spiritually inflected topics are often condemned as essentialist, escapist, naïve, or in other ways apolitical and backward thinking" (Keating 2008, 55). Anzaldúa recognized this bias by asserting, "These knowledges you bring in with your body and your soul and your spiritual practice are not accepted" (Lara 2008, 51). However, scholars and authors who have takenup her works through the application of disability theory are by default engaging with her mindbodyspirit autohistoria-teoría. Her stories of chronic illness in combination with her use of Nepantla, the Coatlicue state and the Coyolxauhqui imperative served Anzaldúa as a form of self-healing and rejuvenation. Such stories "reveal how illness is lived and responded to, defining relationships among body, self, and society" (Langellier 2001, 146).

With respect to her works, some have argued that "since disability-related issues are so rarely explored outside disability studies, reading Anzaldúa's writing as disability narratives would expand other scholars' understanding" (McMaster 2008, 102). Robert McRuer, renown author in the field of queer disability studies, refers to Anzaldúa as a "crip theorist" and her writings as "bridge-building" within the multiple disciplines $(2006,39)$. What we know is that Anzaldúa, herself, did not identify as disabled, or as a diabetic, but rather as saying she had disabilities and that she struggled with diabetes $(2009,299)$. She explained her reasoning by stating the following:

I don't identify as disabled or as a diabetic for several reasons: 1) 'disabled' would reduce me to an even more partial identity than chicana, feminist, queer, \& any other genetic/cultural slice-of-the-pie terms do. \& 2) Diabetic would make me a victim. But neither do I deny or reject the fact that I am disabled in some manner or that I suffer from diabetes \& its complications. (2009, 300).

Her thinking coincides with feminist scholar, Alison Kafer's assertions that disabled bodies, as well as bodies with chronic illness, are often viewed or labeled as "unnatural, sick, degenerate, and deviant" $(2013,45)$.

Regardless of which socialized markers of identity Anzaldúa claimed, she serves as a model for using autohistoria-teoría as a theoretical tool for deconstructing self-perceptions and societal perceptions of disability and chronic illness that are demeaning and oppressive. She recognized that she was living with disability and chronic illness and incorporated her life experiences as disabled and diabetic into her mindbodyspirit embodiment and praxis. As mentioned earlier, she could not ignore what was happening to her body, or to her mental state, but writing about what she was experiencing brought her clarity and triggered her shadow beast. She navigated through the stages of Nepantla, the Coatlicue state and the Coyolxauhqui imperative. Disability became one more piece (metaphorically speaking per 
Coyolxauhqui) to be reintegrated into Anzaldúa's new stories of who she was and who she wanted to become. Essentially, chronic illness served her as another crossroads where she developed what McRuer notes as a "critical disability consciousness" (2006, 80). In Borderlands/La Frontera, Anzaldúa describes crossroads as places "where phenomena tend to collide" and she states that although the process of crossing may be painful, the reward comes from the energy derived from the "continual creative motion" used to break down old paradigms and create new ways of understanding $(1987 / 1999,102)$. It is in the crossroads generated by moments of conocimiento that "traces of agency, resistance and hope ... are legible where identity disintegrates" and "where it comes together" (McRuer 2006, 145).

Anzaldúa has provided her life stories as autohistoria-teoría contextualizing her culture, socio-political history, multiple identities, including disability and chronic illness, and indigenous spiritual beliefs in connection with mindbodyspirit and spiritual mestizaje. Through her writings, she encourages us to spend time in Nepantla, where the borderlands of identity are fluid and create spaces for the holistic integration of mind, body and soul. Anzaldúa viewed people, including herself, who entered willingly (or in some cases unwillingly) into Nepantla as Nepantleras. Nepantleras are "threshold people: they move within and among multiple, often conflicting, worlds and refuse to align themselves exclusively with any single individual, group, or belief system" (Keating 2006, 6). Anzaldúa's own vision of her role as a Nepantlera included considering Nepantla home and acting as a bridge-builder for the spaces in-between with "psychic/spiritual/material points of transformation" (Keating 2006, 8). Nepantleras create inclusive and transformative spaces dismantling systems of power and privilege and forging new frameworks for imagining new realities and new ways of being. Perez implies that we are all Nepantleras to some extent, as Nepantla is "an ambiguous, tentative, ever-changing space we all inhabit" $(2005,1)$. In conclusion, the value of reading and applying her work with multiple theoretical frameworks resides in the commonality that "we are all disabled by injustice and oppression of various kinds" (Davis 2002, 32). Anzaldúa writes about creating a path of knowledge that involves both knowing and learning, and that functions as a way of balancing $(1987 / 1999,41)$. May we all travel that path together in mind, body and spirit.

The body doesn't stop at the skin, ... it extends - Anzaldúa (2000)

\section{References}

Anderson, Kim. 2000. A Recognition of being: Reconstructing native womanhood. Toronto: Sumach Press.

Anzaldúa, Gloria. 1987/1999. Borderlands/La Frontera: The New mestiza. $2^{\text {nd }}$. San Francisco: Aunt Lute Books.

--- 1998. Chicana artists: Exploring nepantla, el lugar de la frontera. In The Latino studies reader: Culture, economy \& society, ed. Antonia Darder and Rodolfo D. Torres. Malden: Blackwell Publishing Ltd.

--- 2002. Now let us shift ... the path of conocimiento ... inner work, public acts. In This Bridge we call home: Radical visions for transformations, eds. Gloria E. Anzaldúa and AnaLouise Keating. New York: Routledge.

--- 2009. The Gloria Anzaldúa reader, ed. AnaLouise Keating. Durham: Duke University Press.

--- 2015. Light in the dark/Luz en lo oscuro: Rewriting identity, spirituality, reality, ed. AnaLouise Keating. Durham: Duke University Press.

Anzaldúa, Gloria, and AnaLouise Keating (eds.). 2002. This Bridge we call home: Radical visions for transformations. New York: Routledge.

Blake, Debbie, and Carmen Abrego. 2000. Doing gigs: An Interview with Debbie Blake and Carmen

Abrego (1994). In Interviews/Entrevistas: Gloria E. Anzaldúa, ed. AnaLouise Keating. New York: Routledge.

Blake, Debra J. 2008. Chicana sexuality and gender: Cultural reconfiguring in literature, oral history and art. Durham: Duke University Press.

Bost, Suzanne. 2010. Encarnación: Illness and body politics in Chicana feminist literature. New York: Fordham University Press.

--- 2010b. Caminando con Gloria: Walking as experience, thought and action. In El Mundo zurdo: Selected works from the meetings of the society for the study of Gloria Anzaldúa 2007 \& 2009, ed. Norma E. Cantú, Christina L. Gutiérrez, Norma Alarcón and Rita E. Urquijo-Ruiz. San Francisco: Aunt Lute Books. 
Brockmeier, Jens, and Donal Carbaugh (eds). 2001. Narrative and identity: Studies in autobiography, self and culture. Philadelphia: John Benjamins Publishing Company.

Cantú, Norma E. et al. (eds.). 2010. El Mundo zurdo: Selected works from the meetings of the society for the study of Gloria Anzaldúa 2007 \& 2009. San Francisco: Aunt Lute Books.

Davis, Lennard J. 2002. Bending over backwards: Disability, dismodernism \& other difficult positions. New York: New York University Press.

Delgadillo, Theresa. 2011. Spiritual mestizaje: Religion, gender, race and nation in contemporary Chicana narrative. Durham: Duke University Press.

Facio, Elisa, and Irene Lara (eds). 2014. Fleshing the spirit: Spirituality and activism in Chicana, Latin and Indigenous women's lives. Tucson: The University of Arizona Press

Freeman, Mark. 2001. From substance to story: Narrative, identity, and the reconstruction of the self. In Narrative and identity: Studies in autobiography, self and culture, ed. Jens Brockmeier and Donal Carbaugh. Philadelphia: John Benjamins Publishing Company.

Garland-Thomson, Rosemarie. 2011. Integrating disability, transforming feminist theory. In Feminist disability studies, ed. Kim Q. Hall. Bloomington: Indiana University Press.

Hall, Kim Q. 2011. Feminist disability studies. Bloomington: Indiana University Press.

Kafer, Alison. 2013. Feminist, queer, crip. Bloomington: Indiana University Press.

Keating, AnaLouise (ed.). 2000. Interviews/Entrevistas: Gloria E. Anzaldúa. New York: Routledge.

--- 2000. Last works? spirit journeys an interview with AnaLouise Keating (1998-1999). In Interviews/Entrevistas: Gloria E. Anzaldúa, ed. AnaLouise Keating. New York: Routledge.

--- 2006. From Borderlands and new mestizas to nepantla and nepantleras: Anzaldúan theories for social change. Human Architecture: Journal of the Sociology of Self-Knowledge 4(3): 5-16.

--- 2008. "I'm a citizen of the universe": Gloria Anzaldúa's spiritual activism as catalyst for social change. Feminist Studies: 53-69.

--- (ed.) 2008. EntreMundos/AmongWorlds: New perspectives on Gloria Anzaldúa.New York: Palgrave Macmillian.

--- (ed.) 2009. The Gloria Anzaldúa reader. Durham: Duke University Press.

Langellier, Kristin. 2001. "You're marked": Breast cancer, tattoo, and the narrative performance of identity. In Narrative and identity: Studies in autobiography, self, and culture, ed. Jens Brockmeier and Donal Carbaugh. Philadelphia: John Benjamins Publishing Company.

Lara, Irene. 2008. Daughter of coatlicue: An Interview with Gloria Anzaldúa. In EntreMundos/AmongWorlds: New perspectives on Gloria Anzaldúa, ed. AnaLouise Keating. New York: Palgrave Macmillan.

McMaster, Carrie. 2008. Negotiating paradoxical spaces: Women, disabilities, and the experience of nepantla. In EntreMundos/AmongWorlds: New perspectives on Gloria Anzladúa, ed. AnaLouise Keating. New York: Palgrave Macmillan.

McRuer, Robert. 2006. Crip theory: Cultural signs of queerness and disability. New York: New York University Press.

Medina, Lara. 2010. Nepantla spirituality: Negotiating fluid identities, faiths, and practices. In El Mundo zurdo: Selected works from the meetings of the society for the study of Gloria Anzaldúa 2007 \& 2009, ed. Norma E. Cantú, Christina L. Gutiérrez, Norma Alarcón and Rita E. Urquijo-Ruiz. San Francisco: Aunt Lute Books.

--- 2014. Nepantla spirituality: My path to the source(s) of healing. In Fleshing the spirit: Spirituality and activism in Chicana, Latina, and Indigenous women's lives, eds. Elisa Facio and Irene Lara. Tucson: The University of Arizona Press.

Ouellette, Grace. 2002. The Fourth world: An Indigenous perspective on feminism and aboriginal women's activism. Halifax: Fernwood Publishing.

Pérez, Emma. 2005. Gloria Anzaldúa: La Gran nueva mestiza theorist, writer, activist-scholar. NWSA Journal 17(2): 1-10.

Ramlow, Todd R. 2006. Bodies in the borderlands: Gloria Anzaldúa's and David Wojnarowicz's Mobility Machines. MELUS 31(3): 169-187.

Reti, Irene. 2008. Living in the house of Nepantla. In EntreMundos/AmongWorlds: New perspectives on Gloria Anzaldúa, ed. AnaLouise Keating. New York: Palgrave Macmillan.

Weiland, Christine. 2000. Within the crossroads: Lesbian/feminist/spiritual development - an interview with Christine Weiland (1983). In Interviews/Entrevistas: Gloria E. Anzaldúa, ed. AnaLouise Keating. New York: Routledge. 